\title{
The effect of rollover footwear on head and trunk posture during standing
}

\author{
Fateme Pol ${ }^{1}$, Saeed Forghany ${ }^{1,2^{*}}$, Christopher Nester ${ }^{2}$, Atefe Rahimi ${ }^{1}$ \\ From 4th Congress of the International Foot and Ankle Biomechanics (i-FAB) Community \\ Busan, Korea. 8-11 April 2014
}

\section{Background}

Footwear with a curved sole profile has become popular due to the proposed benefits to gait, posture and altered muscle activity and tone. In addition, rocker profiled footwear are one of the most commonly prescribed therapeutic shoes [1-4]. The altered movement of the body over the foot due to the curved sole profile is assumed to alter the position of the hips and thereafter the trunk, spine and perhaps the head too. This could have some benefits for those with back pain [5]. However, whilst evidence for the effects on the lower limb is becoming comprehensive [1-4], there is a paucity of information for any effects on head and trunk posture.

\section{Aim}

To investigate the effect of rollover footwear on head and trunk posture during standing.

\section{Material and methods}

Head and trunk posture data of ten healthy female participants(age: $24.5 \pm 1.8$ years) was collected during one minute of quiet standing in two conditions (1) barefoot and (2) rollover footwear (Perfect Steps). The positions of 11 markers mounted on the spinous processes of S2, L5, L3, L1,
T11, T9, T7, T5, T3, C7 and midpoint of forehead were collected by an eight-camera motion capture system at $100 \mathrm{~Hz}$. The planar angles of head and neck, and the radii of thoracic and lumbar curve in the sagittal plane were calculated using an approach described by Forghany et al [6].

\section{Results}

The radius of lumbar curve was decreased significantly by $11.2 \%$ wearing the rollover footwear compared to the barefoot condition $(\mathrm{p}<0.05)$ (i.e. spine more extended). The radius of thoracic curve also increased (i.e. spine also more extended) but the differences were not statistically significant $(\mathrm{p}=0.3)$. Participants wearing the rollover footwear showed significant increase in the planar angles of head and neck by $7.8 \%$ in comparison with barefoot condition ( $p=0.01)$ (i.e. head and neck more extended). (Table 1).

\section{Conclusion}

The current study showed that rollover footwear is able to modify head and trunk posture in quiet standing compared to barefoot. Participants stood more erect in footwear than barefoot. These shoes could therefore have a role in the management of some conditions where an increase in back

Table 1 Head and trunk postural changes wearing the rollover footwear in comparison with barefoot condition during standing.

\begin{tabular}{|c|c|c|c|c|}
\hline & Barefoot & Rollover footwear & $P$ value & \%differences \\
\hline Radius of lumbar curve $(\mathrm{cm})$ & 16.6 & 14.8 & 0.0003 & -10.8 \\
\hline Radius of thoracic curve $(\mathrm{cm})$ & 39.6 & 41.5 & 0.3 & 4.8 \\
\hline Head- $C_{7}$ angle (degree) & 34.8 & 37.5 & 0.01 & 7.8 \\
\hline
\end{tabular}

* Correspondence: Saeed_forghany@rehab.mui.ac.ir

${ }^{1}$ Musculoskeletal Research Centre, Isfahan University of Medical Sciences, Iran

Full list of author information is available at the end of the article 
extension is desirable but the clinical relevance of those changes remains to be determined.

\section{Authors' details}

${ }^{1}$ Musculoskeletal Research Centre, Isfahan University of Medical Sciences,

Iran. ${ }^{2}$ Centre for Health Sciences Research, University of Salford, UK.

Published: 8 April 2014

\section{References}

1. Nigg B, Hintzen S, Ferber R: Effect of an unstable shoe construction on lower extremity gait characteristics. In Clin Biomech. Volume 21. Bristol, Avon; 2006:82-8.

2. Demura T, Demura SI: The effects of shoes with a rounded soft sole in the anterior-posterior direction on leg joint angle and muscle activity. In Foot. Volume 17. Edinburgh, Scotland; 2012:17.

3. Taniguchi M, Tateuchi H, Takeoka T, Ichihashi N: Kinematic and kinetic characteristics of Masai Barefoot Technology footwear. Gait Posture 2012, 35:567-72.

4. Forghany S, Nester CJ, Richards B, Hatton AL, Liu A: Rollover footwear affects lower limb biomechanics during walking. Gait Posture 2013.

5. Nigg B, Federolf PA, Davis E, Lindsay D, Emery C: Unstable shoes and low back pain in golf. Footwear Sci 2011, 3:S121-S2.

6. Forghany S, Nester C, Richards B, Hatton A: Effect of rollover footwear on metabolic cost of ambulation, lower limb kinematics, kinetics, and EMG related muscle activity during walking. J Foot Ankle Res 2012, 5:1.

doi:10.1186/1757-1146-7-S1-A21

Cite this article as: Pol et al:: The effect of rollover footwear on head and trunk posture during standing. Journal of Foot and Ankle Research 2014 7(Suppl 1):A21.

\section{Submit your next manuscript to BioMed Central and take full advantage of:}

- Convenient online submission

- Thorough peer review

- No space constraints or color figure charges

- Immediate publication on acceptance

- Inclusion in PubMed, CAS, Scopus and Google Scholar

- Research which is freely available for redistribution 